\title{
The Development of Adult Education System in Ukraine: Basic Stages and Modern Structure
}

\author{
Nataliya Makhinya* \\ Cherkasy State Technological University, Cherkasy, Ukraine \\ *Corresponding author: zhmurko_n@mail.ru
}

Received September 21, 2014; Revised October 30, 2014; Accepted December 14, 2014

\begin{abstract}
The article focuses on the main stages of development of adult education system in Ukraine. The focus is made on the analysis of the influence the traditions of the past have left in the modern system of adult education. The author underlines the importance of studying the historical processes taking place in its development. Having been the part of Russian empire and later the USSR, the country went through the common process of formation, faced the common challenges, and formed similar with the neighbors' system of adult education. To adapt the lifelong learning system to the new, changed conditions, it is necessary to understand its basic stages and carefully implement world's best experience into existing realities.
\end{abstract}

Keywords: Adult education, lifelong learning, formal education, informal education, non-formal education

Cite This Article: Nataliya Makhinya, "The Development of Adult Education System in Ukraine: Basic Stages and Modern Structure.” American Journal of Educational Research, vol. 2, no. 12B (2014): 11-15. doi: 10.12691/education-2-12B-3.

\section{Introduction}

Adult learning has long been the focus of attention among educators all over the world. Now that progress in science and technology is in pace, issues concerning adult education have come to the force in the Ukrainian system of education, too, both in practice and in theoretical research.

But adult education has not become a complex structure in the system of Ukrainian lifelong education yet. The creation of such a system is a goal for the Ukrainian Ministry of Education. It is a pleasure to say that theoretical foundations for adult education have been successfully developed by the specialized ministry department. Speaking about functional existence, though, present adult education exists in the shape of separate schools, both formal and non-formal, not covered by any general conception of adult learning.

\section{Subject}

The Chinese proverb wisely recommends, 'When planning the program for a year, sow rye. When planning the program for a decade, plant a tree. When planning for the whole life, bring up and educate people' [1].

The rapid development of technology, increased competition and consumer demand lead to the need for lifelong learning, "...from early childhood to old age - and in different contexts: formal (at educational institutions), informally at work place informally in social life" [2].
Accents in education have largely shifted over the recent years. The system crisis arising from new challenges of our society encourages us to review and rethink both - goals of acquiring knowledge and educational time measurement.

Quick and unstoppable development of new technologies requires constant mobilization of forces and opportunities for learning and acquiring more and more skills. Knowledge is currently the center of activity and development of individuals and society in general. It is personal capital, special means to achieve success in life. Constant, continuous education promotes a deeper understanding of events and processes that prevent unemployment, humiliation and discrimination.

Acquiring new knowledge is necessary for both professional work and leisure, since requirements to qualification are increasing, and therefore the value of knowledge in the process of personal self-realization increases, too. Due to the rapid aging of knowledge, people get into the situation when education received before is insufficient to fully participate in the social, industrial and individual processes. The issue of finding a solution in the situation becomes urgent.

Adult education as a part of lifelong learning system has long been under study of many foreign and domestic scientists. We used to search for the ways of its developing anywhere. We used to think that the answers to all our questions in this sphere could be found in European countries, American continent, somewhere in highly-developed societies.

To our mind, it is high time to draw the attention to the Ukrainian experience in teaching adults. The country has rich traditions in the sphere, so we should study them 
thoroughly to decide on which of them to count in reforming the lifelong learning system.

\section{Materials and Methods}

At this stage, requirements for adult education sharply increase to meet the spiritual and educational needs of people engaged in independent professional activity. The value of adult education today is also increased by economic restructuring and the consequent necessity of retraining a significant number of people of working age, and the active involvement of citizens in social and political life in a democratic society.

Taking into consideration the interests and age characteristics of adults in each country its own system of adult education is being developed, the system of specialized agencies of general and vocational education, cultural, educational, entertainment facilities, etc. At present it is the organic component of the education system of the country, which purpose is to promote the comprehensive development of the individual during adult life. In this sense, adult education is a social institution that generates process of transformation of existing society, socio-cultural experience of all its members and consequently, it provides enriching of individual potential.

Ukrainian pedagogical science pays significant attention to the development of adult education. Yet it should be noted that this issue is still at the stage of formation. In the late XX - early XXI APS of Ukraine made an important step for further development of the system of adult education. The 'Main Directions of Educational and Psychological Research in Ukraine", approved by APS of Ukraine, has designated units and the approximate directions of the subjects and research problems of andragogics. In 2007, Institute of Pedagogy and Psychology of Professional Education was transformed into the Institute of Teacher Education and Adult Education of APS of Ukraine. In its structure the department of andragogics was formed.

Search for Ukraine's own model of the national policy on adult education, development and implementation of the Concept of adult education, effective activities of various institutions in the field require understanding of existing problems in the context of pan-European paradigm. Currently, is a necessity for analysis of international legal documents; creating and strengthening of our own regulations implementing the strategic objectives of an effective national system of adult education; systematic and detailed analysis of the theoretical principles and practices of adult education in the developed countries of the world; identification of trends of modern methodology in adult education and development of criteria for adaptation of world practice of adult education into the national experience.

But we shouldn't forget about the peculiarities of our existing traditions in adult educations for they are to be the basis of the further development in the branch.

\section{Results}

Taking into consideration that Ukraine has long been under pressure of Russia, its ruling traces are also noticeable in Ukrainian system of education, too.

It should be mentioned that the adult population was quite actively educated in the former USSR; say, in 1989 about 70 million people $(42.7 \%$ of the 164 million of active population) took part in various forms of adult education [3].

But historical background of this educational phenomenon is far more serious. It started at the middle of the $19^{\text {th }}$ century. The first Sunday schools for adults were founded in Ukraine, being the part of Russian empire, in 1859. The demand was great, so that such schools met with wide public acceptance and their number grew rapidly. There were 200 of them on the territory of Russian Empire in 1860, 300 in 1862 and 1,656 in 1905, with 89,000 students [4,5].

Other kinds of educational institutions emerged, concerned mainly with providing education for adults: reading rooms, reading circles, evening schools and people's universities. Their objective was to spread literacy, culture and advanced social ideas among the population.

Schools for adults delivered education at various levels. The majority limited their activity to creating literacy, but some extended their offer to partial or complete programs of secondary education, sometimes even up to the level of higher education. All schools for adults were characterized by the some democracy and the flexibility of curricula.

It should be stated that a foundation for the theory of adult education in the country was laid in the nineteenth century. An article 'The Sunday Schools' by K. D. Ushinsky (1824-1871), a famous Soviet pedagogue of Ukrainian origin, was published in 1861. The author set out a basic curriculum for Sunday schools which should contain the following fields of study:

- religious history;

- state history;

- physical phenomena;

- the main animal species;

- mental arithmetics, related to measurement, weight, time, etc.;

- drawing;

- crafts;

- major technical inventions.

Konstantin Ushinsky formulated a number of fundamental principles in the education of adults. Most of them are still important today. Among them are:

- the connection of adult learning with the student's work;

- practical objectives in learning;

- the use of adults' life experience;

- the importance of visual aids;

- the importance of recognising individual learner's needs;

- the developing lifelong character of adult education.

In his book, K. Ushinsky wrote, 'The main task of Sunday schools is to awaken the intellectual abilities of learners to act independently.' Another, related task of adult education was to develop 'the desire and the ability of students to obtain new knowledge independently of the teacher ... to be able to learn throughout their life' [6]. 
At the beginning of the $20^{\text {th }}$ century, adult education was actively developed in Ukraine. Distinguished scientists created and selected training programs for adults being completely different from those for children. Special teaching aids were developed and adopted.

The book 'What the Nation Should Read' by Kh. D. Alchevska was awarded a golden medal at the Paris World Exhibition in 1889. In its three volumes, the women teachers of the Kharkiv Sunday school of Ukraine headed by Kh. D. Alchevska discussed the problems of creating reading books for the out-of-school (extra-mural) education of adults [7].

Thus, by the 1900s, the basic principles of adult education had been developed. They were discussed largely at the first Congress of the People's Universities' Personnel (1908) and the first Congress on Popular Education (1914). At that time adult education was known as extra-mural education. In Basic Problems of Organization of Extra-mural Education in Russia (1909), V.I. Charnolussky described the extra-mural education of the time. It included:

- schools for adults, establishments offering reading facilities (libraries, publishing houses, booksellers');

- the organizations spreading knowledge among the population through courses, public lectures, etc.;

- public recreational and sports organizations, museums and art galleries and the so-called people's houses.

But despite the huge efforts of state intellectuals to spread knowledge among the people, only $28.4 \%$ of the population aged between the ages of 9 and 49 registering in 1897 were literate (40.3\% male and $16.6 \%$ female) [8].

After the revolution of 1917, the elimination of illiteracy became one of the main challenges for the Soviet state. In particular, extra-mural education was developed. Only four days after the revolution, on October, 29, the People's Commissar of Education wrote that 'schools for adults should be given an important place in the system of popular education' [9] (Gornostayev, 1974). In December 1919, a decree on Eliminating Illiteracy among the Population of the Russian Federation was adopted by the Soviet government. Adult education was discussed at congresses of the Bolshevist party, at the congress on education in 1918 and at the congress on extra-mural education in 1919. V.I. Ulyanov-Lenin, Chairman of the Council of People's Commissars, made a speech to that congress, in which he emphasized the importance of this kind of education for the economic, social and political development of Soviet society.

In November 1917, the Department of Extra-mural Education was created at the People's Ministry of Education. N.K. Krupskaya, a famous Communist leader, was its head. A year later, the Institute of Extra-mural Education was established at Petrograd, with the aim of carrying out scientific research on non-school education. In 1919, the magazine Extra-mural Education was launched.

Soon a network of general education courses for adults, adult schools, higher peasants' schools, workers' schools and people's universities started to emerge. The workers' faculties appeared, for workers to receive accelerated preparatory courses before entering high school.

Huge efforts in state and public organizations led to the fact that more than 40 million people became literate during the twenties and thirties. By 1939, the proportion of literate population in the USSR had reached $87.4 \%$ (93.5 of the male population and $81.6 \%$ of the female [9]. After World War II, adult education continued to develop, and by 1970, 99.7\% of the population aged between 9 and 49 was literate [8].

In the post-war period, the Soviet government adopted a series of laws on adult education (1958 and 1973). The Ministries of Enlightenment and Higher Education and the USSR State Committee on Education monitored the processes of adult education.

At that time, before proclaiming the Ukrainian independence, the following forms of adult education became established in Ukraine. Some of these forms are kept till now.

Formal education

- general secondary education in evening secondary schools

- vocational education in evening and day-time vocational schools and vocational courses

- secondary specialized education by correspondence in special correspondence secondary schools and evening and correspondence departments of regular secondary specialized schools

- higher education in special correspondence institutes and evening and correspondence departments of regular (day-time) institutes

- post-graduate training for those with higher or secondary specialized degrees in institutes and in departments of higher and further education.

Non-formal education

- professionally oriented and general courses in people's universities and in centers of lifelong education, adult education centers and by means of public lectures and through television or the Internet.

The main feature of adult education in Ukraine was the evening school and the correspondence form, so that people could learn without leaving their jobs. Formal postgraduate education and the specialized courses were mainly full-time and held during the day. Paid leave was offered to those taking examinations, and those who chose to study in the evening had their working time shortened by two hours. All formal education diplomas, whether taken in the evening, through correspondence courses or in day-time provision, had equal validity.

Recently there has been a boom in the development of non-formal adult education, with new kinds of institutions emerging and numbers of students growing. The most widespread form of non-formal education is at the people's universities. This form appeared as early as the nineteenth century, following the example of Western Europe. Since then, such universities have developed considerably, from schools which concentrated on popular literacy to multi-functional enterprises able to provide training in great variety, up to graduate level. This modern stage began in the 1950s.

The Znaniye (Knowledge) Society was created in 1947. This is an example of the organization for non-formal education which aimed to spread knowledge of different kinds among the population through lectures series. Under its guidance people's universities started developing greatly, first the universities of culture and then those of pedagogy, science and technology, agriculture and others. In 1973, a law was adopted which included people's 
universities in the state educational system. By 1987 there were 47,657 people's universities in the Soviet Union, with 18,687,000 students [3].

Along with the people's universities, other kinds of educational enterprises for adults have appeared known as centers of lifelong education and adult education centers. They are aimed at the rapid expansion of training in specific courses for specific purposes, either to enter a new profession or to improve one's qualifications, or to increase one's general level of culture. Courses in foreign languages, business and management, economics, pedagogy, family relations, law, psychology, etc., delivered in the variety of forms already outlined and also by co-operative and state bodies have also become very popular.

In the modern society, the main target of adult education changed completely. Now it is no longer the elimination of illiteracy, but some more serious challenge.

In Ukraine, the concept of adult education is interpreted as a continuous process of education throughout life based on the need to acquire new knowledge and skills. Since learning is a social process, a person is trained for three main reasons:

- For self-improvement;

- For the sake of competitiveness in the labor market (employment, better salaries, career opportunities, employer requirements, acquiring new skills);

- For the more successful social life (compassion, tolerance, decision making, protection of nature those issues require collective solutions and people want to be involved, to express their own opinion).

Continuous education provides lifelong learning, improves skills in accordance with the requirements of the labor market and people's own needs. It combines formal and informal educations, develops both new and innate abilities.

The following benefits of lifelong education are distinguished:

- flexibility;

- diversity;

- availability in time and place of study.

It provides a continuous process of improving both the individual and society, ensures the requests of economic development of the state and civil society development.

In March 20096 a group of researchers of the Institute of Teacher Education and Adult Learning in APS (Team Leader L. Lukyanova) presented a draft of conceptual positions of adult education in Ukraine. In the concept, the basic categories of adult education are specified, the meaning of 'adult education,' 'adult student,' 'adult learning activities,' ‘adult learning technologies' are defined.

The concept was developed in accordance with the decisions of the Fifth International Conference of Adult Education (Hamburg, Germany, 14-18 July, 1997), the International Council for Adult Education (Damascus, Syria, 22-26 September, 2000), Intergovernmental program of the Concept of common educational space of the Commonwealth of Independent States (November 29. 2001), Sofia Conference of Adult Education (Bulgaria, November 9, 2002), the concept of adults in the countries of the Commonwealth of Independent States (Moscow, Russia, May 25, 2006) and subject to the provisions of the Model law ‘On Adult Education' (December 7, 2002) [10].
Analysis of future specialists training in Ukraine and requirements of the modern labor market shows that currently there are some differences between the result of training and the requirements of employers. The last require professionals, competent not only in their professional activities, but also capable of self-education, personal development, social interaction in multinational information society. The main qualities of modern professional are the ability to solve complex social and industrial problems, professional versatility. So the institutions must stop to train for economic problems that have lost or are losing their value.

The modern economy demands regular supplement of knowledge and skills from specialists in the professional development. The researchers note that in order to achieve social success, modern person has to change the scope of professional activities at least four times. For those working in the same industry for a long time, it is necessary to update and improve their skills at least once every three years.

\section{Conclusion}

According to Alvin Tofler, the famous American futurist, illiterate man of the XXI century is not the one who can not read and write, but the one who does not know how to learn and how to be retrained [1].

The need to optimize the adult education system is due to the importance of improving the policy, regulatory support, funding for this sector as well as the contents, methods and forms of organization of postgraduate education, training, identifying the theoretical and methodological foundations of psychological and pedagogical patterns of effective teaching, developing psychological teacher recommendations, etc.

Implementation of the tasks mentioned above is difficult to imagine without realizing of the country traditions in the related sphere, though. We should be aware of who we are and what our history is about. Only doing so, we can properly develop the system of our Ukrainian adult education in accordance with the best world traditions.

\section{References}

[1] Makhinya, N. "Features and prospects of development of adult education in France," Humanitarian Bulletin "PereyaslavKhmelnitsky State Pedagogical University named by $H$. Skovoroda," 3 (31). Jun. 2014.

[2] Lifelong learning in the new economy (Series "Actual issues of education") Alex, Moscow, 2006, 264.

[3] Kuznetsov, V. Education and Culture in the USSR, Open Learning, Paris: Unesco, 1975.

[4] Gornostayev, P. The Theory of General Adult Education before the October Revolution and in the First Years after the Revolution. Moscow, 1974, 6.

[5] Vladislavlev, A. "The Conceptual Framework for Lifelong Education in the USSR.” Unesco Journals, Paris, 1978, 128.

[6] Ushinskiy, K. Pedagogical Works, Volume 2. Moscow, 1988, 65-68.

[7] B. Bim-Bad, L. Sokolova, S. Zmeyov "Perspectives of adult education in Russia,” Official site Pedagogical Library, January 2007. [Online]. Available: http://www.bimbad.ru/biblioteka/article_full.php?aid. [Accessed Sept. 7, 2014].

[8] Onushkin, V. Tonkonogaya, E. Adult Education in the USSR, Prague, 1984, 97. 
[9] Gretchishkin, V. “Socialism and Education,” Moscow, 1976, 18.

[10] Makhinya, N., Tkachenko, L. "Psychological and pedagogical conditions for implementation of European standards in adult education of Ukraine," Humanitarian Bulletin "PereyaslavKhmelnitsky State Pedagogical University named by $H$. Skovoroda," 27 (40). May 2012. 